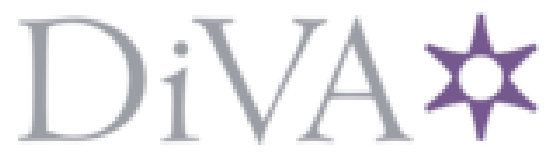

http://www.diva-portal.org

\title{
Postprint
}

This is the accepted version of a paper published in Journal of Gaming \& Virtual Worlds. This paper has been peer-reviewed but does not include the final publisher proof-corrections or journal pagination.

Citation for the original published paper (version of record):

Kirkpatrick, G., Mazierska, E., Kristensen, L. (2016)

Marxism and the computer game.

Journal of Gaming \& Virtual Worlds, 8(2): 117-130

http://dx.doi.org/10.1386

Access to the published version may require subscription.

N.B. When citing this work, cite the original published paper.

Permanent link to this version:

http://urn.kb.se/resolve?urn=urn:nbn:se:his:diva-13061 


\section{Marxism and the computer game}

Graeme Kirkpatrick, University of Manchester

Ewa Mazierska, University of Central Lancashire

Lars Kristensen, University of Skövde

\section{Abstract}

This article asks the question, how should the computer game as a new cultural form be assessed from a Marxist perspective? Marxism is a developed theoretical discourse operative in several domains that are potentially relevant to computer games. The first part of our discussion focuses on Marx's discussion of technology in relation to art and presents his historical dialectic of alienation and disalienation. This dialectic highlights the ambivalence of technology: it is both the condition of possibility of a society of a plenty in which humanity is freed from drudgery and yet, with each step forward, it is associated with the imposition of new demands and novel forms of oppression. Viewed in this way, computer games are an important manifestation of digital technology, deeply implicated in new forms of capitalism. In the second section we use Marx's ideas on art to explore the aesthetics of the new medium. The aesthetic occupies a special place in Marxist thought because it defines a space of reflection in which we can find a momentary escape from the fray of conflictual social relations and from which the future may shine a light. Viewed as a form of art, computer games are also ambivalent. On one side, they have been associated with a revival of play and a new culture of levity and creativity, which has spread as far as contemporary workplaces and even transformed the design of industrial, or productive, technology. At the same time, we argue that there has been no corresponding social transformation - people are not more free as a result of 'gamification'. Rather, it seems that computer games present a 
deepening entanglement of aesthetic values (play, freedom, imagination) with technologies of control (interface, system, rules). In conclusion, we suggest that digital games bring the dream of art to life but that the result is not freedom but rather a perversion of play as its facility for opening up imagined spaces is used to restrict access to the space of freedom.

\section{Keywords}

Marxism

Play theory

Game industry

Aesthetics

work

technology

\section{Introduction}

This article argues that the computer game presents a challenge to Marxist theory. Digital games are central to a changed cultural landscape in which Marxist explanations and practical interventions inspired by Marxist ideals struggle to gain traction. If anyone doubts the importance of computer games to critique of contemporary society they may be persuaded by the sheer economic significance of the form: games are the largest part of today's global media industries, with an annual value far in excess of film, and they are far and away the fastest growing entertainment sector. More than this, though, since their appearance in the late 1970s computer games have altered the way people relate to technology, to each other and to the wider world. The practices of interactivity and of digital culture have been introduced to people through this medium as generations of children have now played games and learnt about computers through the experience. Women play games as much as men and 
the average age of gamers has been put at the late 30s. Computer games are, then, culturally salient as well as economically significant, and deeply imbricated in what is widely agreed to be a new form of capitalism in which digital technologies form the dominant infrastructure.

This article starts by identifying the parts of Marx's theory that seem most relevant to analysing the computer game as a cultural form. Section one focuses on Marx's discussion of technology in relation to art and presents his dialectic of alienation and disalienation. New technologies, we suggest, play into this dialectic, in which Marx highlights the ambivalence of technology as it liberates humanity from various kinds of drudgery and enhances productive power on one side, while at the same time it diminishes the quality of the labour process and imposes new physical demands on workers on the other. This contradictory process has a further, aesthetic dimension for Marx because as well as making demands on workers' bodies it also stretches and reconfigures them in various ways, making it possible for them to perceive the world differently. This aesthetic broadening, so to speak, enhances the expressive potential of the species, but under capitalism this is squandered as the new levels of responsiveness are used merely as openings for capitalists to cultivate false needs and manipulate peoples' behaviour through advertising and other strategies. The contradictory nature of technology and art under capitalism is deeply intertwined and it is here that we should position the computer game as a new form.

In the second section we develop this idea by looking at contemporary capitalism. Drawing on recent scholarship on the nature of the capitalist economy and work in the digital age, especially the work of Luc Boltanski and Eve Chiapello (2005), we identify broad continuities with earlier phases of capitalist development. Like the earlier generation of machines, computers have been used to enhance managerial control over production. However, there are also important discontinuities. In particular, the demand for a less routinized and physically demanding form of work, raised by young workers in the wake of 
1968 , led to a management strategy of aestheticization applied to the work process. As one of us has argued at length elsewhere (Kirkpatrick 2013), this process extended to digital technology itself. The tools of the modern workplace are colourful and supposedly 'easy to use'. This situation, from the basic principles of user interface design to the more recent 'gamification' of numerous labour processes, has been directly informed by the development of games. At the same time, it bears directly upon how computer games themselves are produced.

Having situated computer games in the context of a Marxist understanding of contemporary capitalism we turn in conclusion to look directly at the character of computer games. We argue that, viewed in terms of Marx's dialectic of alienation and disalienation, computer games should be understood primarily as aesthetic objects, rather than as parts of an ideological media system. Analyses that focus on game contents to position them as 'neoliberal texts', or whatever, are mainly wide of the mark. Instead, we should understand games as ambivalent between authentic art and manipulative commodities. They reflect an intensification of Marx's dialectic in which aspects of subjective, inner nature that were previously withheld from the logic of the system have been drawn into its reproduction. Insofar as it facilitates free play, aesthetic experience should be a locus of greater autonomy, pointing us towards a situation in which production and creativity are fused together. However, instead of this, with computer games we now find that play itself is targeted by manipulative predatory forces intent on turning the powers of the free imagination against itself.

\section{Marx, technology, aesthetics}

Marx's theory of history was the first to state what has since become commonplace - namely, that the development of technology drives historical change. When he described technology Marx emphasized its role in production and in transforming the labour process. Technologies, 
he says, represent the application of human intentions and purposes to the natural world. The underlying logic of these purposes is the desire to be free from want, or, as Marx calls it, the 'heteronomy of needs' (Marx 1981). By winning more leverage over the world we establish the possibility of real autonomy. Where bourgeois philosophers argue that this can be achieved through changes in the way that we think, Marx counters that it is enhanced technological control and material production that make freedom possible.

At the same time as technology enhances control by imposing human designs onto raw matter, so to speak, so it also entangles humans in new sets of rules. In creating a sphere of activity that stands over nature and subjects it to human purposes we generate a kind of feedback loop in virtue of which we are ourselves subject to new kinds of control. Tools enhance our power of action on the world but to use them we have to comply with the rules of their operation. Marx views this in dialectical terms:

Man not only effects a change of form in the materials of nature; he also realizes his own purpose in those materials. And this is a purpose he is conscious of, it determines the mode of his activity with the rigidity of a law, and he must subordinate his will to it. This subordination is no mere momentary act. Apart from the exertion of the working organs, a purposeful will is required for the entire duration of the work. This means close attention. The less he is attracted by the nature of the work (and the way in which this has to be accomplished) and the less, therefore, he enjoys it as the free play of his own physical and mental powers, the closer his attention is forced to be. (Marx 1990: 284) 
For Marx, the impact of technology on the labour process was correspondingly unpleasant, even though its role in the longitudinal historical process was inherently progressive.

Marx sometimes emphasizes that this split in the fate of technology is distinctive to the capitalist social formation as it emerged in the eighteenth century. On one side, new productive machines tend to impact negatively on the labour process, shattering the unity of human creative endeavour and fragmenting experience. Craft workers used decorated, personalized implements to fashion a product and were involved in the process from start to finish. In contrast, industrial workers were reduced to guiding a machine in the repetitive performance of a small part of the creative process, never seeing the final product. Alienation from the product of their labour here intensifies, penetrating and diminishing their life activity.

At the same time, by enlarging the capacities of the human creature, technology also has a role to play in the counter-movement through which workers, Marx argued, will ultimately be able to re-appropriate both their labour and its products. In the socialist future, work will become 'life's prime want' - our way of expressing ourselves - as well as a way of contributing to technologically enabled economic super-abundance.

An often neglected aspect of this dialectic pertains to the senses of the human animal, which, as Rousseau had already pointed out (Rousseau [1754] 1984), were changed by social history as well as by natural evolution. As Morawski (1974) points out, there is an aesthetic dimension to the dialectic of alienation and disalienation. In the Economic and Philosophic Manuscripts of 1844 (1977), Marx discusses the impact of the historical process in general, and industrial technology in particular, on the senses of the human animal. 
Only through the objectively unfolded richness of man's essential being is the richness of subjective human sensibility (a musical ear, an eye for the beauty of form - in short, senses capable of human gratifications, senses confirming themselves as essential powers of man) either cultivated or brought into being... The forming of the five senses is a labour of the entire history of the world down to the present. (Morawski 1974: 52)

There is a dialectic of the senses, which are stimulated in their development by new means of production; yet these enhancements rarely get used for anything other than viewing the world more effectively as 'raw materials' to be exploited.

Nonetheless, technology enlarges the range of cultural possibilities. It mutilates the experience of workers but also facilitates new expressive capabilities. There is, therefore, an aesthetic dialectic of technology development in which techniques shape their users and in so doing make them into the kind of people who could use technologies as creative tools and even as raw material for art.

However, here too the potential of technology is subject to a systematic negation by capitalist social reality. Rather than enrichment of the senses opening out onto new more diverse kinds of experience, the differentiation of our sensory capacities only serves in practice to make us more prone to the predations of the market. Marx writes that

The increase in the quantity of objects is accompanied by an extension of the realm of the alien powers to which man is subjected and every new 
product represents a new potency of mutual swindling and mutual plundering...

Through advertising and other kinds of manipulation, capitalism stimulates...

the other's most depraved fancies, plays the pimp between him and his needs, excites him in his morbid appetites, lies in wait for each of his weaknesses. (Morawski 1974: 61-62)

Within the creative sphere of the arts the dialectical process of alienation/disalienation plays out again. The enormous potential of technology works to produce a more differentiated and complex human nature only to use this as the basis for further negation of its potential, especially its capacity for self-emancipation. As Marx puts it, 'culture... is, for the enormous majority, a mere training to act as a machine' (Marx 1967: 99).

Marx did not get the opportunity to develop this dialectic into a fully elaborated theory of art. However, his few remarks have set the scene for a large critical tradition of scholarship in which the aesthetic is understood as an unfolding realm of human potential that is constantly negated by the competitive economic system of production for profit. This theoretical perspective can be applied to computer games, which have played a vital role in digitization, including shaping 'serious' uses of computers. The context for this is the change to industrial production attendant upon what Luc Boltanski and Eve Chiapello (2005) call the 'artistic critique' of labour and the 'great refusal' of industrial work, which happened in the 1970s. The way that capitalism responded to this amounts to a 're-aestheticization' of technology 
and of work. This transformation is inseparable from the rise of the computer game as a popular entertainment form.

\section{Digital capitalism and 'artistic critique'}

Marxist theory in all its guises maintains the centrality of production. Glossy, attractive commodities loaded with seductive promises all have to be made, often in sweatshops dominated by abusive overseers or in distributed software environments where no one gets to sleep however bored they are. Moreover, the logic of the production process plays an overdetermining role, conditioning what gets produced, shaping it to the demands of the market and controlling both costs and labour. There is a contradiction between the forms of capitalist organization and artistic creativity, which is well known within the games industry. Capitalist control is exerted through technology, management of the production process and framing of the games industry as somewhere people, especially younger workers, want to work.

First, there is a high demand for the products offered by game designers. Those working in computer games are perceived as being at the cutting edge of contemporary industry, or even in the avant-garde. This is reflected in the re-shaping of the academic environment, where media studies increasingly incorporate game studies, often in expectation that this will alleviate the problem of declining student numbers. ${ }^{1}$ Second, it is still a new profession; hence, it is expected that the worker can shape it herself or himself to a higher degree than if she or he entered an older profession, where ground rules were established by previous generations. Third and most importantly, it is creative work. Game designers are artists and their chance of producing new things is higher than in the case of film-makers (with whom they are most often compared), because the technology they use changes faster than that at the disposal of film-makers. Needless to say, under current circumstances it is film-makers who often learn from game designers rather than the other way around (Boxer 2013; Lenhardt and Rauscher 2015), as demonstrated by a large number of films whose narrative 
structure is similar to that of the game. Lola rennt/Run, Lola, Run (1998) by Tom Tykwer is an early example of this trend.

Although labour is at the centre of Marx's writings, he devotes relatively little space to the discussion of different categories of employees and uses industrial work as a model to describe work at large, which is understandable in the light of the fact that he created his theories when factory work was the dominant form of labour. Marx condemned such work, most importantly in his passages devoted to alienation in Economic and Philosophic Manuscripts of 1844 (1977). First, he argued that such work is physically very hard. The industrial worker is a wretched man or a woman, who achieves any pleasure or comfort only outside his or her workplace and dies prematurely because of physical exhaustion. The long used metaphor of a worker as a zombie has one of its roots in Marxist writings. The second, closely connected reason why Marx criticizes the capitalist mode of production is that the work and its fruit do not belong to the worker but to the capitalist. The worker earns only as much or rather as little as to be able to survive materially; the rest is appropriated by the capitalist who uses it as capital, to expand his business. 'The wage the labourer receives is always a minimum wage, the lowest compatible with common humanity, that is, with cattlelike existence' (Marx 1977: 71).

Marx concedes that the work of cultural workers under capitalism is physically lighter, but it is also alienated because it has to bring profit to the capitalist (Marx 1969: 411). Moreover, those engaged in creative or intellectual production have to adhere to the dominant ideology. This refers especially to those who require a large initial capital to produce a required cultural good. For this reason, novelists and poets can afford ideological subversion more than filmmakers and game designers. Moreover, makers of high-budget, Hollywood films have had to adhere more closely to the dominant ideology than those producing independent films (Maltby 2003) and we can apply the same logic to computer games. Nevertheless, for Marx 
the main division is that between workers operating under capitalist and socialist systems rather than what kind of work they perform, manual or intellectual.

As we have already said, Marx viewed the impact of capitalist industrial technology on production as contradictory and involving a multi-dimensional dialectic of alienation/disalienation. The digital technological revolution has been no less contradictory. Workers suffer less physical alienation, so to speak, but they are often expected to be committed to and involved in a form of work that is de-personalized and inherently less interesting.

The crucial transition occurred post 1968, when Fordist practices started to be replaced by post-Fordism. According to Luc Boltanski and Eve Chiapello, in France this shift occurred in part as a result of the protest of the workers who complained about the tedium of their labour, what the authors of The New Spirit of Capitalism term 'artistic critique' (Boltanski and Chiapello 2005: 170). Capitalists bowed to the desire of employees to make their work more versatile and creative, noticing that this might increase productivity and thus help accumulation of surplus value. At the same time they ignored the call for greater job security and a higher standard of living, what Boltanski and Chiapello term 'social critique' (2005: 169). Understandably, in due course the requirement to be always creative, continuously reinventing not only his product but even herself, produced a backlash. The character of alienation changes so that contemporary workers crave authenticity, and this desire is met through the proliferation of new commodities like organic foods, which, paradoxically, are commodities that are desirable because they appear to come from outside the realm of commodity production (Boltanski and Chiapello 2005: 443). ${ }^{2}$

Production of computer games takes place in such a post-Fordist, deregulated world, where each worker is not only allowed to be creative but required to be so. Moreover, game 
development takes place under conditions of neo-liberalism (Kirkpatrick 2013; de Peuter and Dyer-Witheford 2009), rather than embedded capitalism, which often offered state protection to certain expensive art forms, such as European arthouse cinema. Designers of games do not receive such protection and it is unlikely for their creators to be feted as defenders of national culture or universal values. The relatively small group of game designers who escaped anonymity, such as the inventor of Mario, Shigero Miyamoto, the designer of Pokemon, Satoshi Tajiri, or Markus Persson of Minecraft, achieved their positions more due to sheer popularity of their games and the profit they created for their companies and themselves rather than the perceived cultural or pedagogic value of their products. They have a lower profile in comparison with film directors such as Jean-Luc Godard, Michelangelo Antonioni or Ken Loach, who are regarded not only as film-makers but also as public intellectuals, although this situation keeps changing, as demonstrated by a growing literature concerning the game auteurs (Dewinter 2015).

According to Mark Deuze, the organization of the games industry has:

A distinct hourglass structure, with a few corporate hardware manufacturers (Microsoft, Sony, Nintendo) and multinational publishers (such as EA, THQ, Activision, UbiSoft and Konami) at one end, and a diverse network of thousands of small studios and service agencies at the other - and very few mid-sized companies in between. (2007: 342)

Not surprisingly, the fruit of the work in this industry is divided unevenly, with those at the top collecting the most of the cake and those at the bottom receiving little, indeed often 
putting many more hours than if they were employed as waged labourers, working under the Fordist regime.

Workers in the game industry perfectly fit the concept of 'precariat': the new practically rightless proletariat, which differs from the old proletariat largely in being better educated and employed in services (see Deuze et al. 2007; Kucklich 2005). The freedom of game designers to wear informal clothes at work is paid for by the necessity to work long hours, which partly explains why women are rarely attracted to this profession. ${ }^{3}$ Moreover, from the manuals for prospective designers we can gather (and our 'anecdotal' research confirms this) that the level of unionization in game industry, as in all creative industries, is low. In summary, a typical employee of game industry is a slave wearing a mantel of a bohemian artist. We can even suggest that the privilege to pose as a bohemian is an important reason why game design is so appealing to young men.

Computer games have developed in tandem with the growing hegemony of the neo-liberal socio-economic model. We can even argue that, the more advanced computer games are, the more they are in tune with neo-liberal ideology. For example, the principle of freemium, adopted by many leading game companies, such as Finnish Supercell, the creators of 'Clash of Clans', can be regarded as a typical neo-liberal strategy, used also by drug dealers. Freemium capitalists initially give something for free, not out of genuine charity but in expectation that the user will get addicted to the product she or he received and will have to buy not only more of the same but its improved (and more costly) version.

Perhaps the clearest illustration of the affinity of games with neo-liberal strategies of accumulation and governance is provided by massive multiplayer online games (MMPGs). On the face of it these games present fantasy worlds of escape where people might meet others who also seek self-expression and real connection. Entering these game worlds players 
must craft an avatar, which they then use to present themselves to others in the game. Working with other players is normally essential to success in the game and meeting people is widely cited as one of the principle pleasures of gameplay. These games are utopias in which people can recuperate from the rigours of work and engage in playful exploration.

Studies have shown, however, that the player experience of these worlds is deeply ambivalent. As Humphreys $(2008,2009)$ and Ruch (2009) have demonstrated, the game world cannot be straightforwardly equated with the technical designs, graphical features and programmed objects that supposedly constitute the game. Rather, what sustains player interest and creates the feeling of worldness is invariably the activity of other players. Players perform the game for each other and in this sense they co-create it, but their labour is owned by the corporation. Moreover, much of the 'play' is not playful at all, on any standard definition, but actually resembles coerced labour. In order to progress in the game - to be useful to other players and thereby get included in guilds, teams, etc. - players need to possess in-game objects and experience points and these can usually only be obtained by engaging in tedious procedures, sometimes referred to as 'grinding' parts of the technical environment. This leads David Golumbia (2009: 196) to argue that what we see here is 'extensions of physical economies into our own ideological imaginaries', so that what is advertised as 'play' comes to resemble work in the digital economy. Finally, the quality of the social interaction itself falls short of anything that might be genuinely recuperative for the player, in the sense that it is largely conditional on successful performance of in-game goals. In other words, players are being judged and assessed on how well they do, just as they are when they are at work. The personal connections established are therefore based on anonymous and alien standards and, as such, not really personal at all.

It should be added that computer games, even more than arcade games, are often addressed to children, as reflected by them drawing on fairy-tale characters, narratives and images, as well 
as on earlier games for children, such as Lego in the case of Minecraft. But, of course, their supposed child-friendliness is based on the assumption that children part with money easier than adults, as confirmed by stories of children who blew thousands of pounds or dollars playing games on their computer. The fact that contemporary games can be played in the privacy of one bedroom render them more predatory (see Plowman et al. 2010; Aarsand and Aronsson 2009; Hill 2011).

The majority of games, including 'Clash of the Clans', define the success of the player in terms of neo-liberal success. He or she has to constantly accumulate goods, with gold and elixir being the privileged possessions, reflecting the value of money and youth, which are not directly translatable to each other, but connected. The second requirement is to destroy his or her enemies and fortify his or her houses, in expectations of attack from enemy forces, which can be seen as an allegory of a permanent 'state of war' (Hardt and Negri 2006: 3-62) and obsession about security (Harvey 2005: 64-86), pertaining to post-Cold War world order. Moreover, computer games can go on forever, reflecting the fact that (unlike socialism) capitalism has no defined goal; it can proceed indefinitely, accumulating and dispossessing more and more on the way. At best or worst it can achieve the state of delirium, as represented by popular myth of the exhausted gamer who cannot stop playing, even to eat.

The question arises whether, given the mode of production and character of computer games, there is any chance that their producers will create games advocating socialist ideals, most importantly equality. Again, if we turn to Marx, then the answer should be positive. This is because the realization of one's position - namely, being a member of a dispossessed proletariat - might lead to a desire to resist this state by creating unions, opposing the precariazation of game industry and advocating a different world through the product created. However, at the moment the odds against this state of affairs are high given, on the one hand, the near-hegemonic position of neo-liberal industry and the perception that the more 
successful is the game in mimicking neo-liberal order, the greater is its chance of commercial success, which is practically the only type of success that matters.

\section{Aesthetic critique}

Marx and Engels are often associated with 'ideology-critique' as their preferred methodology for appraising cultural and artistic works, in light of the contradictions discussed above. This is largely because, aside from a few remarks about Greek sculpture (Morawski 1974: 64), the bulk of Marx's writing on art concerned literature. Novels, poems and plays are perhaps peculiarly susceptible to this kind of critique, because, in the nineteenth century at any rate, they are concerned with communicating a meaning, most often telling a story. The significance of a story in ideological terms concerns whether it enlightens workers as to the real underlying cause of their alienation. If it does then a work may be deemed progressive, in the context of the dialectic described above of aesthetic potential as against manipulation for commercial ends. This led in the twentieth century to Marxism's disastrous association with 'socialist realism' as the approved, communist aesthetic.

Paintings and musical works, however, are far less open to such analysis because the level of experience on which they operate is not 'literal' or even straightforwardly representational. To be sure, paintings and other visual media often appear to be 'of' something else but there is wide recognition in the sphere of art appraisal that what really matters about paintings is less a matter of verisimilitude and more a question of painterly style, or the way the representation has been executed. With music the range of questions is perhaps even broader and further removed from resolution through discussions of 'realism'.

It is almost tautologous to point out that video games are not representational media in the manner of texts or even photographs, because everything that goes on in them exists under the horizon of 'gameness'. The fact that something 'is only a game' necessarily blunts its 
significance, where the latter is taken to derive from correspondence to something else. Games stand as invitations to play with what they seem to represent: the player gets inside the video game image just as the image works on the body of the player, obliging them to use the controller, to ride the tensions that are produced between what the game appears to be about and what it feels like to play (Swink 2009). This is not to say that games have no textual or literary capacities, only that these must be understood as one plane of an experience that is necessarily constituted out of many intersecting levels of interaction.

Notwithstanding the undeveloped nature of Marx's aesthetic theory, it would not be true to say that Marx had nothing to say about this kind of aesthetic. Starting from his observations on the historical transformations of the senses and his comments on Greek sculpture, we can detect an idea of form in his work that applies to interactive and playful media. Marx praises classical sculpture because it involved 'complete forms'. These aesthetic products reflect the fact that in Greece it was recognized that all production was, in a sense, of the human being. This contrasts with modern political economy, where production is to create wealth by meeting 'needs' that are identified as properties of the historical human, once it has embarked on the historical process described previously. In other words, modern production is 'onesided' (Marx 1977) and this is reflected in artistic production as well.

The notion that a more authentic art might be more rounded out and expresses a fuller human truth is not developed anywhere in Marx's writings. In particular, there is no exploration in his work of art's response to its stymied and marginal position under capitalism. This was a line of argument that was famously developed further by others in the Marxist tradition, especially Adorno (2002). There we find the notion that aesthetic form preserves itself not by seeking to establish (inauthentic) reconciliation that runs ahead of the historical process, but rather by collapsing in on itself. As Adorno writes, art in the twentieth century preserves itself by renouncing art (beauty) and becoming something ugly. Only in this way, by 
shocking and disturbing us, can it remain true to its ultimate vocation - 'the splinter in your eye is the best magnifying glass' (Adorno 1978).

There is an evident disconnect between Adorno's theory of modern and abstract art on one side and the computer game on the other. Computer games rarely shock in the sense that modern art did. This might lead us to question whether an aesthetic approach is the correct one to take. However, games do offer experiences of form and we can plausibly suggest that these correspond to an innate sense of measure, ${ }^{4}$ something that we cleave from the dark matter of the computer. If we accept that the aesthetic definition of computer games is correct then this has implications for the way that they should be appraised in Marxist perspective. A key term here is play, which defines our interaction with computer games and is also a key term for Marxist analysis.

Play holds an important place in Marxist social thought, not least because it has long been the antonym to work, which is central to any serious understanding of society and culture. Marx inherited a conception of human creativity that was strongly infused with the notion of play from his forebears in the German tradition of critical social thought, especially Friedrich von Schiller ([1793] 2008). Consequently, Morawski detects in Marx an opposition between what he calls homo faber and homo ludens. Like Schiller, ${ }^{5}$ Marx believed that when humans were free they would play and produce - the two sides of our vital activity would be reunited.

The recent changes to capitalism are perhaps most unsettling for Marxism when they touch on this question of the ultimate abolition or transformation of work. The current entanglement of play and work represents a step half taken in the negation of work by play, the overturning of the heteronomy of labour by the active force of imagination in freely shaping social relations. Viewed this way it sometimes seems as if the future Marx glimpsed, in which a massive expansion of productive power liberates humanity from the obligation to 
work, is staring us in the face, yet we still cannot grasp it. Marx wrote that 'the world has long since possessed something in the form of a dream which it need only take possession of consciously, in order to possess it in reality' (cited in Lukacs 1971: 2). Computer gameplay and the associated gamification of other practices puts us in ambiguous territory with respect to this. With the foregrounding of play in entertainment, where it increasingly resembles work, and the aestheticization of work through the infusion of playful values, we seem to stop dreaming about freedom by taking hold of it consciously; yet, still we do not have it in reality.

The contemporary culture of play, associated most strongly with video games, then appears as a particular source of frustration because here the heteronomy of work seems to have reached right into the play of the imagination to still it - or worse, turned it into its opposite.

As Boltanski and Chiapello argue, the contemporary 'streamlined worker' is encouraged to reflect constantly on how he or she can make himself or herself more effective and competitive. This means that critical self-reflection, something integral to the development of one's own real capabilities and ultimately even one's understanding of one's life and its meaning in the grand scheme of things, gets drawn into work (Mazierska 2015: 198-257). This mirrors the point made above concerning play - its foregrounding ought to represent a step to liberation, yet it takes us nowhere. Similarly, exercising a degree of control over one's work and using one's critical powers of reflection ought, in the classical Marxist problematic, to reflect a recovery of autonomy. Instead, feeling that one's 'real self' is at stake in this way creates a more pervasive sentiment of inauthenticity. No longer serviceable as the basis for anti-capitalist critique, the consequence of this is discernible in a range of symptomatic practices from interest in yoga to consumption of organic foods (Boltanski and Chiapello 2005: 441). 
It makes sense to position computer games here as commodities that do not simply disappoint but actually intensify the entanglement of the subject in the system that produces this dissatisfaction and sense of meaninglessness in the first place. Seduced by the promise of better play, the gamer works harder to achieve goals that are inherently meaningless. This is necessary preparation for a work environment that involves similar procedures - we learn the habits of computer use by playing computer games - involving people personally and drawing directly on their most creative faculties yet denying them ownership of or real control over the results. What Engels (in Morawski 1974: 63) understood to be the recuperative powers of play are harnessed here to enhance the hold of the system and, by channelling play at source, to prevent play from performing its traditional role of opening up spaces for the imagination. In other words, the more we play with video games and other digital devices, the more we control and limit the play that could set us free.

\section{References}

Aarsand, P. A. and Aronsson, K. (2009), 'Gaming and territorial negotiations in family life', Childhood, 16:4, pp. 497-517.

Aarseth, Espen (2015), 'Meta-game studies', Game Studies Journal, 15:1.

Adorno, T. W. (1978), Minima Moralia (trans. E. F. N. Jephcott), London: Verso. (2002), Aesthetic Theory (trans. R. Hullot-Kentor), London: Continuum.

Boltanski, L. and Chiapello, E. (2005), The New Spirit of Capitalism, London: Verso.

Boxer, Steve (2013), 'How video games are transforming film industry', The Guardian, 17 November, http://www.theguardian.com/technology/shortcuts/2013/nov/17/videogames-transforming-film-industry. Accessed 12 October 2015.

Deuze, M. (2007), Media Work, Cambridge: Polity. 
Deuze, M., Martin, Bowen and Allen, C. (2007), 'The professional identity of game workers', Convergence, 13:4, pp. 335-53.

Dewinter, Jennifer (2015), Shigeru Miyamoto, London: Bloomsbury.

De Peuter, G. and Dyer-Witheford, N. (2009), Games of Empire: Global Capitalism and Video Games, Minnesota: University of Minneapolis Press.

Dovey, J. and Kennedy, H. (2006), Game Cultures: Computer Games as New Media, Maidenhead: McGraw-Hill.

Gane, N. and Beer, D. (2008), New Media: The Key Concepts, London: Berg Press.

Golumbia, D. (2009), ‘Games without play’, New Literary History, 40:1, pp. 179-204.

Hardt, Michael and Negri, Antonio (2006), Multitude: War and Democracy in the Age of Empire, London: Penguin.

Harvey, David (2005), A Brief History of Neoliberalism, Oxford: Oxford University Press.

Hill, J. A. (2011), 'Endangered childhoods: How consumerism is impacting child and youth identity', Media, Culture \& Society, 33:3, pp. 347-62.

Humphreys, S. (2008), 'Ruling the virtual world: Governance in massively multiplayer online games', European Journal of Cultural Studies, 11:2, pp. 149-71.

(2009), 'Norrath: New forms, old institutions', Game Studies, 9:1.

Kirkpatrick, G. (2013), Computer Games and the Social Imaginary, Cambridge: Polity. (2015), 'Ludefaction: fracking the radical imaginary', Games \& Culture 10(6) pp507524.

Kline, S., Dyer-Witheford, N. and de Peuter, G. (2003), Digital Play: The Interaction of Technology, Play and Marketing, Montreal: McGill-Queens University Press. 
Kucklich, J. (2005), 'Precarious playbour: Modders and the digital games industry', Fibreculture Journal, 5.

Lenhardt, E. and Rauscher, A. (eds) (2015), Films and Games: Interactions, Frankfurt am Main: Deutsches Filminstitut.

Lukacs, G. (1971), History and Class Consciousness, London: Merlin Press.

Maltby, Richard (2004), Hollywood Cinema, Oxford: Wiley-Blackwell.

Marx, K. (1969), Theories of Surplus Value, London: Lawrence and Wishart. (1977), Economic and Philosophic Manuscripts of 1844, Moscow: Progress Publishers. (1981), Grundrisse (trans. M. Nicolaus), Harmondsworth: Penguin. (1990), Capital: A Critique of Political Economy Volume 1, London: Penguin Books in association with New Left Review.

Marx, K. and Engels, F. (1947), The German Ideology, Parts I and III, New York: International Publishers. (1967), The Communist Manifesto, London: Penguin Books.

Mazierska, E. (2015), From Self-Fulfilment to Survival of the Fittest: Work in European Cinema from the 1960s to the Present, London and New York: Berghahn Books.

Morawski, S. (1974), Karl Marx and Frederick Engels on Literature and Art: A Selection of Writings (eds Lee Baxandall and Stefan Morawski; intro. Stefan Morawski), New York: International General.

Plowman, L., McPake, J. and Stephen, C. (2010), 'The technologisation of childhood? Young children and technology in the home', Children \& Society, 24:1, pp. 63-74. 
Rousseau, J.-J. ([1754] 1984), Discourse on Inequality (trans. Maurice Cranston), London: Penguin Classics.

Ruch, A. (2009), 'World of Warcraft: Service or space?', Game Studies, 9:2.

Schiller, F. von ([1793] 2008), Letters on the Aesthetic Education of Man, Montana: Kessinger.

Swink, S. (2009), Game Feel: A Game Designer's Guide to Virtual Sensation, Amsterdam: Morgan Kaufmann.

\section{Contributor details}

Graeme Kirkpatrick is Senior Lecturer in Sociology at the University of Manchester and writes on technology, art and critical theory. He co-edited Historical Materialism and Social Evolution (Palgrave, 2002) and has written several books, including Aesthetic Theory and the Video Game (Manchester University Press, 2011), Computer Games and the Social Imaginary (Polity, 2013) and The Formation of Gaming Culture (Palgrave, 2015). His current work focuses on the meanings of 'critique' and its relation to aesthetics.

Ewa Mazierska is Professor of Film Studies at the School of Humanities and Social Sciences, University of Central Lancashire. She has published over twenty monographs and edited collections on film and popular music. A large proportion of them use Marxism as its principal lens. They include Marx at the Movies: Revisiting History, Theory and Practice (Palgrave, 2014) and Marxism and Film Activism: Screening Alternative Worlds (Berghahn, 2015) (both edited collections, co-edited with Lars Kristensen) and a monograph From Self- 
Fulfilment to Survival of the Fittest: Work in European Cinema from the 1960s till Now (Berghahn, 2015).

Lars Kristensen is Lecturer in Media, Aesthetics and Narration at the University of Skövde, where he teaches moving image theory to game developers. Current research topics include bicycle cinema and the intersection between computer games, film and fine art. $\mathrm{He}$ is the editor of Postcommunist Film - Russia, Eastern Europe and World Culture (Routledge, 2012), Postcolonial Approaches to Eastern European Cinema (co-edited with Ewa Mazierska and Eva Näripea, I. B.Tauris, 2014), Marx at the Movies (co-edited with Ewa Mazierska, Palgrave Macmillan, 2014) and Marxism and Film Activism (co-edited with Ewa Mazierska, Berghahn 2015).

Contact:

Arthur Lewis Building, Oxford Road, Manchester M13 9PL, UK.

E-mail: Graeme.Kirkpatrick@manchester.ac.uk

Greenbank Building, GR 233, Lancashire, Preston PR1 2HE, UK.

E-mail: EHMazierska@uclan.ac.uk

School of Informatics, Box 408, 54128 Skövde, Sweden.

E-mail: lars.kristensen@his.se

Notes 
${ }^{1}$ This is facilitated by studies of 'new media' that purport to address games while actually treating them as a subset of something else. Gane and Beer (2008), for instance, purport to cover games by including a text box about 'Guitar Hero'. We should also note that the new discipline of computer game studies has recently proclaimed itself victorious in establishing a new field of study (see Aarseth 2015), effectively insulating games from critical scholarly analysis.

${ }^{2}$ At the same time, they argue, anti-capitalist critique in the name of authenticity becomes 'ridiculous' and anachronistic (Boltanski and Chiapello 2005: 453).

${ }^{3}$ The most promising line of explanation for the under-representation of women in the games industry concerns the cultural and symbolic coding of games and gameplay and a male domain. This affects the environment around games as well as their content and design (see Dovey and Kennedy [2006] and for a historical discussion see Kirkpatrick [2015]).

${ }^{4}$ In the 1844 manuscripts Marx writes that 'man... knows how to produce in accordance with the measure of every species and knows how to apply everywhere the inherent measure to the object. Man, therefore, also forms things in accordance with the laws of beauty' (cited in Morawski 1974: 51).

5 'Man', Schiller writes, 'only plays when in the full meaning of the word, he is a man, and he is only completely a man when he plays' (2008: 34). This idea is central to Marx's thought too, as suggested by this famous passage from The German Ideology, when borrowing from the utopian socialist, Charles Fourier, he proclaims (in a somewhat country gentleman fashion) that the all-rounded individuals of the communist future will be 'hunting in the 
morning, fishing in the afternoon', without becoming professional hunters or fishermen (Marx and Engels 1947: 22). 